\title{
Symbiont Bacteria of Mangrove Organic Waste as Consortium Bacteria, Cellulose Degrading Bacteria and Antibacterial Agent
}

\author{
Delianis Pringgenies ${ }^{1 *}$, Ali Djenaedii ${ }^{1}$, Rini Widiyadmi ${ }^{2}$ and Dafit Ariyanto ${ }^{3}$ \\ ${ }^{1}$ Department of Marine Science, Diponegoro University, Indonesia \\ ${ }^{2}$ Islam Al Azhar 14 Senior High School, Indonesia \\ ${ }^{3}$ Department of Agriculture, Asahan University, Indonesia
}

*Corresponding author: Delianis Pringgenies, Department of Marine Science, Diponegoro University, Indonesia.
Received Date: January 14, 2020

Published Date: January 27, 2020

\begin{abstract}
Four species of bacteria, namely Pseudomonas sp., Flavobacterium sp., Acinetobacter sp., and Bacillus subtilis from symbiont bacteria of mangrove organic waste. The bacteria found synergies each other's and potency as cellulose degrading bacteria and antibacterisal agents. consortium bacteria showed promise in water treatment application.
\end{abstract}

Keywords: Consortium; Bacteria; Cellulose degrading; Antibacterial

\section{Introduction}

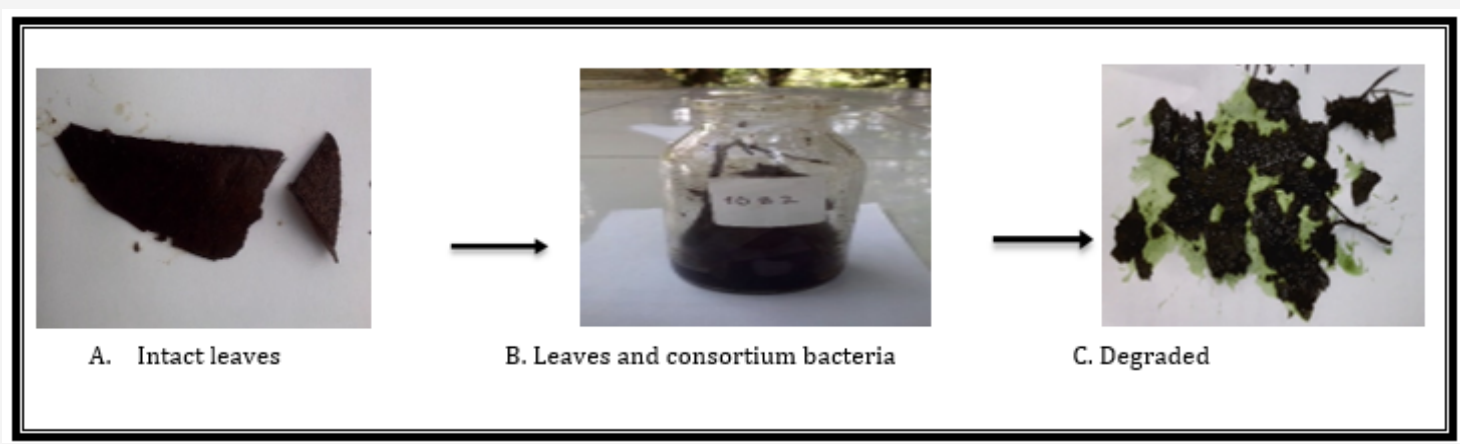

Figure 1: Organic waste which was introduced to consortium bacteria and in the process of degradation.

Synergistic test results of 4 species of bacteria, namely Pseudomonas sp., Flavobacterium sp., Acinetobacter sp., and Bacillus subtilis post a 24 hour incubation period showed that no zone of inhibition was formed on the contact surface of the swabbed isolate samples [1]. This means that all of the bacteria can perform in synergy with each other. The four bacterial species showed potential to be used as consortium bacteria. The cellulolytic activity test against 4 bacteria: Pseudomonas sp., Flavobacterium sp., Acinetobacter sp. and Bacillus subtilis showed that the species: Pseudomonas sp had no cellulolytic activity, while Bacillus subtilis showed the highest cellulolytic activity value which almost covers all its medium. Flavobacterium sp. and Acinetobacter sp. were also shown to have cellulolytic activity. Consortium Bacteria (Pseudomonas sp., Flavobacterium sp., Acinetobacter sp. and Bacillus subtilis) as Cellulose degrading Bacteria. This result confirmed that the consortium of Bacillus sp., Pseudomonas sp., Flavobacterium 
sp., and Acinetobacter sp. has the ability to degrade organic waste, as in previous results, which is presented in Figure 1 below. It was observed that after the introduction of consortium microbe, the organic waste underwent accelerated degradation process. Figure 1A shows the intact state of the waste, Figure 1B shows the introduction of consortium bacteria culture, and Figure 1C shows waste degradation after \pm 2 months of incubation [2] (Figure 1).

The synergistic performance among the species in the consortium was believed to be the main contributing factor of accelerated waste degradation rate. The results of this study, as presented in Figure 1, proved that consortium bacteria had cellulolytic c activities both invitro and in vivo.

\section{Discussion}

The results showed that the consortium bacteria performed effectively as cellulose degrading bacteria and antibacterial agent. The consortium bacteria break down more organic materials, making shreds of the treated leaves smaller than the non treated leaves. This bacterial activity can increase the availability of the nutrient in the soil through mineralization and nitrogen assimilation processes. According to Martinko and Madigan[3], bacteria can live and multiply in dead organisms by breaking down organic compounds such as protein, carbohydrate, and fat by single metabolism process like amino acids, $\mathrm{CO}_{2}$ gas, carbon, nitrogen, hydrogen, oxygen, phosphor, sulfur, or other inorganic elements such as $\mathrm{K}, \mathrm{Mg}$, Ca, Fe, Co, Zn, Cu, Mn, and Ni. The decrease in shred sizes showed change in compost texture, which indicated that the bacteria degraded all the $\mathrm{C}$ elements in the leaves. This in turn gave the compost its grainy texture. Bacteria consortium is specifically capable of increasing nitrogen nutrients. According to Nasahi [4], facultative, anaerobic bacteria such Bacillus as are nonsymbiotic nitrogen fixing bacteria, which can survive because of the availability of nitrogen compounds, inorganic nutrients, energy sources, as well as humidity and high temperatures. Pseudomonas is a species known to increase the availability of phosphor. The increase in temperature can happen during the decomposition, since such activity releases heat. The temperature generally keeps rising until it reaches its maximum limit. After the limit has been reached, the temperature will gradually lower. This is due to gradual decrease in consortium bacteria's decomposing activity. Test results showed in vivo cellulolytic activities by the bacteria. At the end of the observation, there was a change of odor from what was similar to its original material into earthy odor. This change indicated that the bacteria worked perfectly and had successfully broken down the cellulose. A change in color in the leaves was also observed, from brown to black, as presented in Figure 1C. This change in color indicated that the complex $\mathrm{C}$ chain in the material had been broken down into simple $\mathrm{C}$ chain due to the bacteria's activities. Decomposition process causes composted materials to lose their color pigment, changing its color to black, according to its base material. During the decomposition process, the consortium bacteria absorbed water and nutrition from organic materials and break them down, releasing $\mathrm{CO}_{2}$ and $\mathrm{O}_{2}$ as a result.

\section{Conclusion}

1. The results of the study showed that Pseudomonas sp., Flavobacterium sp., Acinetobacter sp. and Bacillus subtilis were potential consortium bacterial species.

2. Flavobacterium sp., Acinetobacter sp. and Bacillus subtilis showed capability as cellulose degrading bacteria.

3. Based on the identified of Pseudomonas sp., Flavobacterium sp., Acinetobacter sp. and Bacillus subtilis, these consortium bacteria showed promise in water treatment application.

\section{Acknowledgement}

None.

\section{Conflict of Interest}

No conflict of interest.

\section{References}

1. Pringgenies D, Izzuddin A, Ali R, Riyanda I (2016) Exploration of Bacteria Symbionts Mangrove Waste for The Production of Decomposter. International Conference on Coastal Zone, Osaka, Japan.

2. Pringgenies D, Rini W, Dafit A, Riyanda I (2018) Organic Compos Production from Bacterial Consortium of Mangrove Leaf Litter. Jurnal Pengelolaan Perairan 1(2): 19-27.

3. Martinko, Madigan (2005) Brock Biology of Microorganisms (11th edn.). International Microbiology 8(2).

4. Nasahi HC (2010) Peran Mikroba dalam Pertanian Organik. Tesis, Bandung, Universitas Padjajaran, Indonesia. 